\title{
“GOSTARIA DE OUVIR TODAS AS HISTÓRIAS QUE PUDER. TODAS.” ENTREVISTA COM O PROFESSOR DR. JOSÉ CARLOS SEBE BOM MEIHY
}

por Suzana Lopes Salgado Ribeiro ${ }^{1}$ e Andrea Paula dos Santos Oliveira Kamensky ${ }^{2}$

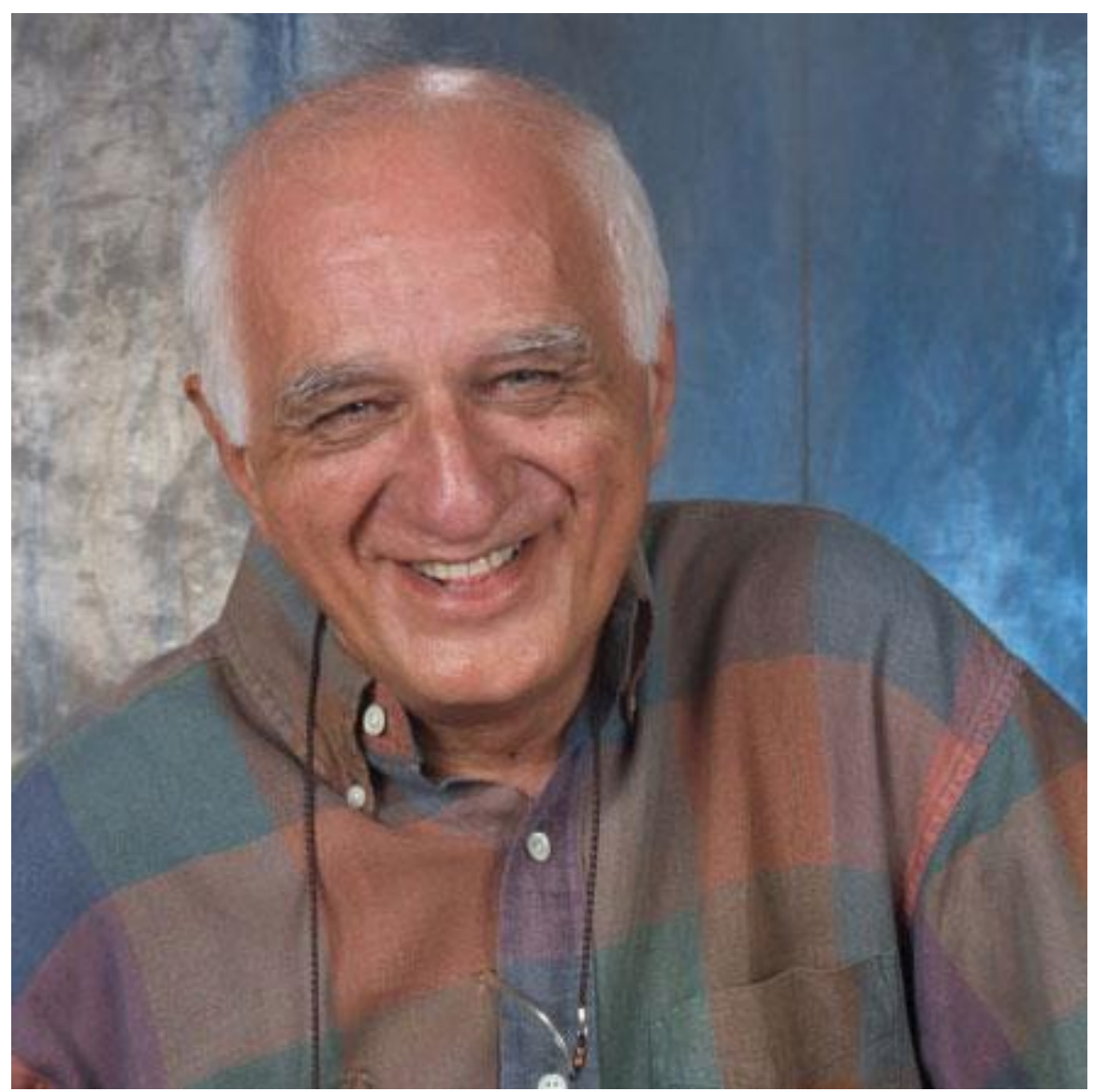

Falar de História Oral em minha vida, depois de mais de 50 anos de vivência escolar, é um pouco refletir sobre a essência profissional. Em sua mais feliz realização diria que, antes de ser oralista, sou professor; antes de ser professor, sou cidadão e, creio que é por aí que abro o conjunto de respostas que remetem a questão da paixão. A vontade de produzir conhecimento a partir dos fatos da vida - da vida real, concreta, imediata - me fez observador das circunstâncias que me explicam. O encadeamento das situações deu-se de maneira quase que natural: como alguém que vive em sociedade me pareceu importante saber do meio em que vivo; saber do meio me levou à história; da história foi mecânico passar à vontade de saber dos

\footnotetext{
${ }^{1}$ UNITAU - Universidade de Taubaté. suzana.ribeiro@ falaescrita.com.br

${ }^{2}$ Universidade Federal do ABC. andrea.santos@ufabc.edu.br
} 
próximos, e a História Oral foi assim se fazendo mediadora de minhas reflexões. Se há paixão, é pela vida.

Sou fruto do meu tempo, é claro. Nasci em um tempo de guerra, em 1943. Ainda que seja discutível a existência de uma geração coerente com o Baby Boom dos países mais diretamente afetados pela Segunda Guerra Mundial, ainda que o Brasil tenha participação singular, acredita-se que o efeito do envolvimento não tenha, entre nós, produzido significativa alteração demográfica. De toda forma, graças ao processo de formação da cultura formal, acadêmica e universitária vigente no Brasil, a influência dos países europeus e a norteamericana foi vigorosa e determinante.

Quem passou pelos chamados “anos de chumbo" (1964/68-1985), experimentou o rigor da ditadura militar e padeceu os efeitos do impedimento democrático em nosso país. Ao mesmo tempo em que olhávamos para os Estados Unidos como apadrinhadores do golpe militar, em nosso cotidiano persistiam outras influências marcantes de nosso cotidiano: cinema, música, literatura, trejeitos comportamentais, roupas... Foi sob essa paisagem que cresci e me tornei professor universitário.

Depois de minha formação na antiga Faculdade de Filosofia, Ciências em Letras de Taubaté, ainda como aluno dos últimos anos, em 1969, comecei minha vida docente nos ginásios locais e percebia a distância entre a história que tinha que ensinar e a vida dos alunos. Ingressando na Universidade de São Paulo (USP) como aluno de pós-graduação em 1975, logo fui convidado pela professora Sônia Siqueira a ser assistente. Na carreira uspiana, fui convidado a dirigir o programa de assistência a alunos estrangeiros, em particular aos norte-americanos. Trabalhei por mais de 20 anos nesse posto e assim convivia com os principais especialistas estadunidenses sobre o Brasil.

A censura nacional imposta pelos militares me fez questionar sobre a visão externa, em particular dos pesquisadores norte-americanos, sobre aquele momento. Diria que saber da vida dessas pessoas me soava como um ato político. Foi uma experiência reveladora de muitos segredos da vida acadêmica. Antes de me lançar ao desafio do registro da vida dos Brasilianistas norte-americanos, escrevi um ensaio que causou bastante mal-estar, intitulado Introdução ao Nacionalismo Acadêmico: os Brasilianistas. ${ }^{3}$ A recepção do livro tanto irritou o público brasileiro como os colegas norte-americanos. A indignação foi tanta por parte dos estrangeiros que me convidaram para conhecer seus espaços de produção. Por mais de um ano fui para os

3 SEBE, José Carlos. Introdução ao Nacionalismo Acadêmico: os Brasilianistas. São Paulo: Brasiliense, 1984. 
Estados Unidos, percorri várias academias e fiz mais de 60 entrevistas. Basicamente, queria saber dos móveis entre a vivência pessoal e a produção intelectual: A Colônia Brasilianista: História Oral de Vida Acadêmica ${ }^{4}$ foi resultado dessa aventura.

O livro Canto de Morte Kaiowá: História Oral de Vida ${ }^{5}$ foi um desafio importante e definitivo em minha trajetória. Feito o livro anterior, em 1991, ofereci um primeiro curso na USP, sobre História Oral. O encantamento de alguns alunos me fez ver a possibilidade de produção de uma história que dissesse diretamente do nosso tempo, nos incluísse. Como devido respeito à História (com letra maiúscula), me parecia oportuno envolver estudantes em questões do tempo presente.

Devo dizer que, desde 1983, em pleno processo de abertura política, juntamente com o colega José Sebastião Witter, havia iniciado um projeto de entrevistas com o pessoal do mundo do futebol, no Museu da Imagem e do Som em São Paulo. Sob a direção de Boris Kossoy tive oportunidade de iniciar outras experiências importantes sobre compositores e intérpretes do Vale do Paraíba Paulista. E assim ia me aprofundando em técnicas de entrevistas.

Vale dizer que, mesmo sendo professor já no quadro regular docente da USP, minha prática de História Oral foi fertilizada fora da academia. Foi, porém, de uma cobrança em sala de aula que se fez oportuna a possibilidade de então fazer um projeto que envolvesse uma problemática efetivamente brasileira: com os povos indígenas. O potencial simbólico era sedutor: trabalhar com os remanescentes nativos, legítimos donos e expropriados do território nacional; cuidar de soluções de produção de fontes documentais de pessoas analfabetas. Fazer isso dentro do Departamento de História da USP era algo mais do que desafio.

Bastou um convite da Universidade Federal do Mato Grosso do Sul, para realizar um minicurso de História Oral, para que fosse com dois alunos para Dourados. Sem exageros, foi uma experiência vital para entendimento do "outro", para ingresso em definições de aspectos subjetivos. Tudo isso atuando em um Departamento devotado ao documento produzido, guardado, de ares inéditos.

Em seguida, um dos trabalhos que fiz foi sobre os brasileiros que foram lutar na Espanha, nas Brigadas Internacionais, ao lado dos republicanos. Outra vez me vi jogado em um universo de interditos. Nos anos de 1980, vivíamos o apodrecimento do poder militar que deixou, além de uma inflação insuportável, um legado de silêncio, vetos e

4 MEIHY, José Carlos Sebe Bom. A Colônia Brasilianista: História Oral de Vida Acadêmica. São Paulo: Nova Stella, 1990.

5 MEIHY, José Carlos Sebe Bom. Canto de Morte Kaiowá: História Oral de Vida. São Paulo: Loyola, 1991. 
apagamento de histórias que latejavam aspirando novos ares. Foi nesse cenário que vi com outros segmentos presentes em diferentes universidades, o fulgor daquilo que em países que passaram por ditaduras, surgir algo emblemado como História Oral. Era um respiro.

A primeira reação que se me apoderou foi de que a História Oral seria um sintoma do comprometimento político democrático. O direito de falar, de gravar, de se mostrar herdeiro de processos históricos próximos ou longínquos sugeria a formulação de um programa de cidadania. Sempre defendi o jargão que professa "a História Oral como atestado da democracia". Confirmo que me mantenho fiel ao posicionamento político da História Oral como expressão do direito à própria história.

Um dos resultados do programa censor promovido pela ditadura remetia ao apagamento da existência de uma esquerda militar brasileira. Imediatamente aliada à direita, me afigurou oportuna a retomada de narrativas dos soldados que, presos no Levante de 1935, na cadeia se definiram como defensores da democracia em nível internacional. Liberados em 1937, o pequeno contingente de 16 militares brasileiros, expulsos de seus quadros funcionais, foram lutar ao lado dos republicanos espanhóis. Entrevistá-los foi uma honra e exercício de trabalho com memórias: pessoais, sociais e historiográficas: A Revolução Possível: História Oral de Soldados Espanhóis na Guerra Civil Espanhola ${ }^{6}$ é um dos trabalhos mais empenhados que fiz. Demorei mais de dez anos até concluí-lo.

Por outro lado, com meu amigo, o brasilianista já falecido, Robert M. Levine, começamos um outro projeto de pesquisa em História Oral. Mas, a história de meu envolvimento com a escritora Carolina Maria de Jesus é tortuosa e, em certa medida, autobiográfica. Era jovem com menos de 20 anos quando li pela primeira vez Quarto de despejo: diário de uma favelada. ${ }^{7}$ Como para o público em geral, aquele que foi o primeiro best seller brasileiro fez vibrar em mim um apelo pela narrativa popular e pelo respeito pelas histórias contadas pelos protagonistas.

Por esse tempo, mantinha fervorosa correspondência com Robert M. Levine que, por sua vez, mostrava-se ardoroso defensor da mulher negra, imigrante, mãe solteira, Carolina. Ele, sobre ela, escreveu um longo ensaio nos idos de 1989. De minha parte, fiz muitos comentários

6 MEIHY, José Carlos Sebe Bom Meihy. A Revolução Possível: História Oral de Soldados Brasileiros na Guerra Civil Espanhola. São Paulo: Xamã, 2009.

7 JESUS, Carolina Maria de. Quarto de Despejo: Diário de uma Favelada. São Paulo: Francisco Alves, 1960.

Rev. Iberoam. Patrim. Histórico-Educativo, Campinas (SP), v. 4, n. 2, p. 220-235, jul./dez. 2018 
e, dessa interação, nasceu Cinderela Negra, a saga de Carolina Maria de Jesus. ${ }^{8}$ Acolhido pela editora Heloísa Buarque de Holanda, o livro foi muito bem recebido e motivou críticas boas e negativas.

Por ironia, exatamente as que detratavam incentivaram debates em torno do ressurgimento (já em tempos de abertura política) de uma mulher icônica, símbolo do renascimento do movimento negro nacional. Ao mesmo tempo, a concepção do livro provocou ecos, pois a ideia central era buscar os personagens arrolados no Quarto de Despejo e ver o que aconteceu com eles 30 anos depois.

Creio que muito mais do que expor o óbvio - de que a obra de Carolina é, sem dúvida, literatura - se mostra importante discutir o direito a produzir documentos sobre si mesmo. E, nesse sentido, a proposta do livro escrito em parceria com Levine amarrava duas pontas de meu projeto pessoal: a ligação possível entre um brasilianista norte-americano e um pesquisador brasileiro. Ao mesmo tempo, promovia a projeção de trabalhos de História Oral, motivando a pesquisa empírica. Devo dizer ainda que, novamente, na produção deste livro atuaram alguns alunos do curso de graduação, pessoas que depois levaram avante o trabalho com oralidade.

Amar é condição de sobrevivência digna. Ninguém vive sem amor. Sobrevive-se sim, em estado vegetativo. Diria que há os amores pessoais e os sociais. Feliz é quem conjuga ambos simultaneamente. Em termos profissionais, optei por uma carreira que exige afinidade com a circunstância docente. Sem amor aos alunos, sem dedicação irrestrita à escola e à constelação escolar não se vive e a educação. Outra vez, é possível sobreviver, mas sem a beleza do convívio e a promessa de continuidades intelectuais.

Em entidades mais plásticas, a opção dos alunos por aulas optativas é sintomática das respostas que buscam. A vivência no campo da História como disciplina acadêmica me ensinou que a liberdade de composição curricular, por menor que seja, é ideal. É justamente no intervalo das grades curriculares que o estudante respira desejos. É verdade que nem sempre é possível furar o bloqueio dos programas instituídos e controlados, mas a flexibilidade possível pode ser encontrada nos critérios de avaliação.

Nesse sentido, sempre busquei dar liberdade aos alunos para assumirem as próprias orientações nos trabalhos finais. Um dos caminhos que encontrei, quase sempre, era incentiválos a proceder estudos sobre a matéria e suas vidas pessoais, familiares, comunitárias. Um exemplo remete à experiência na disciplina História Ibérica. Sob tal chancela, os temas

8 MEIHY, José Carlos Sebe Bom; LEVINE, Robert M. Cinderela Negra: a Saga de Carolina Maria de Jesus. Rio de Janeiro: Ed. UFRJ, 1994. 
remetiam a um passado colonial, distante temporalmente da realidade deles. Então, sugeria que fossem entrevistados portugueses imigrantes que contassem suas percepções. O pretendido era exercitar relações e pensar atemporalidades.

O Núcleo de Estudos em História Oral na USP (NEHO/USP) dimensionou o melhor de minha experiência acadêmica, em mais de 50 anos de vida profissional. Ciente da insuficiência do tempo de aula, da precariedade dos recursos reclusos às salas de aulas e bibliotecas, resolvi promover um debate voltado para a aproximação das abstrações teóricas (sempre exageradamente exploradas em nossos cursos universitários) com iniciações em pesquisas de campo. Nunca concebi como ideal o exagero de explorações que se esgotam na leitura de pensadores. Aliás, creio que este é o maior vício da educação universitária brasileira, no campo da História. Tenho comigo que não se pode falar de teoria sem pesquisa empírica.

Ao pensar o NEHO/USP supus um agrupamento de interessados em temas filtrados pela oralidade. Haveria pois de ser um segmento composto por voluntários, interessados em estudos em geral. Não se requeria filiação escolar e, sobretudo, valorizava-se o convívio. Neste sentido, sempre tivemos em torno de uma mesma mesa evangélicos, pais de santo, psicólogos, jornalistas, pessoal devotado à educação. Diria que a mágica que garante a durabilidade do NEHO/USP remete à combinação da pauta das reuniões e à informalidade. Levamos como lema do grupo: "vamos fazer o que os outros não estão fazendo". E mantivemos sempre o compromisso da troca de experiências.

Pensar nos resultados desse investimento me comove. Temos, em decorrência do convívio do NEHO/USP mais de 50 dissertações e teses, muitos artigos e outras publicações que dimensionam a produção do grupo. Alguns temas marcantes do estágio conseguido pela produção brasileira de História Oral, com segurança, passaram pelos debates do NEHO/USP. Desde a qualificação conceitual de ramos da História Oral (de vida, temática, testemunhal ou tradição oral), até o processo de legitimação das entrevistas, foram pautados.

Diria que do convívio com o grupo, desde sua raiz na nascente de 1991, dois faróis se acenderam mais consequentemente: a criação da Associação Brasileira de História Oral (ABHO) e o número de publicações de resultados. No caso da $\mathrm{ABHO}$, como vice-coordenador do Congresso Internacional "América 92: Raízes e Trajetórias", promovi um encontro agregador de outros grupos interessados na institucionalização da matéria, fato concretizado em 1994.

No circuito mais direto, pensando nas resistências naturais do Departamento de História da USP, organismo prezador da escrita e dos documentos ditos convencionais, me pareceu vital permanecer lá, e produzir reflexões que resultaram, entre outros, nos Manuais de História 
Oral $^{9}$ que, em cinco edições, venderam-se mais de 20 mil exemplares. A felicidade do trabalho com o NEHO/USP pode ser expressada no desdobramento dado pelos antigos alunos, hoje pesquisadores reconhecidos na área.

As fronteiras da História Oral são - e devem se manter - bastante porosas. Seu estatuto acadêmico passou por três estágios principais: desprezo, aceitação relativa, respeitabilidade progressiva. De início, era vista como mera ferramenta, recurso suplementar sem destaque. Daí, graças a abertura política e ao reconhecimento de outras expressões de cidadania, ganhou alguma relevância, não, porém, sem certo desprezo qualitativo. Quando a discussão sobre memória passou a plano destacável, a oralidade alçou proeminência, e assim conseguiu geometricamente pertencer ao rol das expressões respeitáveis.

Num primeiro momento, a História Oral brasileira, como que num arroubo libertário, prestou atenção aos grupos sufocados: exilados, mulheres, negros, homossexuais, reprimidos de toda ordem. Foi nesse diapasão que brilhou o tema dos Sem Terra. Com autonomia, alguns dos participantes do NEHO/USP encararam a proposta, deram-lhe forma exemplar. ${ }^{10}$ Os reconhecimentos desses lances, curiosamente, soaram forte em um dos campos mais abertos à História Oral, ou seja, o jornalismo. Pelas entrevistas retraçam-se planos de diálogos comuns e os resultados são muito prometedores. Sinceramente, não advogo com tanta ênfase os rótulos dados à História Oral. Creio que sua autonomia estatutária é virtude e convite a caracterização como disciplina. Mas isso o tempo dirá.

O livro Augusto e Lea tratava de "um caso de (des)amor em tempos modernos". ${ }^{11}$ A história da produção deste livro é tão interessante como o enredo nele expresso. Tratava-se de uma sondagem sobre os companheiros diretamente implicados em casos de doenças crônicas. Sempre a sociedade em geral presta atenção nos diretamente atingidos, ou seja, nos acometidos. Pouca atenção tem sido dada aos companheiros, acompanhantes, responsáveis pela manutenção da lógica do entorno. Porque passei por problemas afins, em ocasião de uma doença que surpreendeu minha família, e porque me vi como coadjuvante em uma trama que exigia mais de mim do que havia imaginado suportar, comecei pensar nos "outros". Foi assim que me vi, por indicação de uma psicóloga que acompanhava meus filhos frente aos traumas sofridos em

9 MEIHY, José Carlos Sebe Bom. Manual de História Oral. 1ª $2^{\mathrm{a}}, 3^{\mathrm{a}}, 4^{\mathrm{a}}$ e $5^{\mathrm{a}}$ ed. São Paulo: Loyola, 1996-2002. 10 MEIHY, José Carlos Sebe Bom; RIBEIRO, Suzana Lopes Salgado; SANTOS, Andrea Paula dos. Vozes da Marcha pela Terra. São Paulo: Loyola, 1998.

11 MEIHY, José Carlos Sebe Bom Meihy. Augusto e Lea: um caso de (des)amor em tempos modernos. São Paulo: Contexto, 2006. 
conjunto, que me foi sugerido fazer um acompanhamento mais completo do contexto familiar de casos como cardiopatias, paralisias renais, tuberculoses.

Aconteceu que o primeiro caso apresentado foi de um marido que havia transmitido AIDS para a esposa. O mergulho na história dessa família forçou entrevistas com parentes, amigos e acompanhantes. Na situação específica de Lea, não era possível fazer uma única entrevista. A condição de saúde dela, e o amadurecimento discursivo, exigiram repetidas visitas. Um dos ensinamentos imediatos dessa aventura documental foi a discussão sobre entrevistas únicas ou múltiplas. Consequência inerente, foi definir como expressar o composto narrativo, colhido em várias sessões. A finalização do texto se deu em trabalho conjunto com a colaboradora que, afinal, ajudava na argumentação conclusiva. Demorei muito para finalizar este trabalho posto que o apelo sensível era doído demais e, além disso, não me sentia à vontade para terminá-lo em uma fase na qual ainda não tinha devidamente amadurecida a relação entre a história daquele tempo presente e os fundamentos da história profissional, feita na/pela universidade. Senti-me mais livre depois que me aposentei.

Depois de algumas investidas praticamente impulsivas em História Oral - quando adentrei no terreno ainda instintivo de trabalhos como os brasilianistas norte-americanos e com os indígenas brasileiros - resolvi que a experiência com História Oral era um caminho sem voltas. Estando em um Departamento tão ligado à escrita e prezador de documentos estabelecidos, não me restava caminhou outro que não me aprofundar. Foi assim que me propus a levantar critérios estabelecidos para a produção de histórias de vida e, além disso, me exercitar em temas que já haviam sido testados em investidas anteriores.

Diria que a formulação de postulados filosóficos me moveu à busca de fundamentação. Confesso que não me satisfazia a justificação de História Oral como metodologia, técnica, ferramenta. Não tinha, por continuidade, segurança para supô-la como uma disciplina. Ademais faltavam argumentos para uma discussão mais digna sobre o estatuto da História Oral. Por esse tempo, por acaso, soube de uma bolsa de estudos, por um ano, promovido pelo Oral History Office, da Universidade de Columbia, em Nova York, e resolvi me inscrever. Para enfrentar a enorme concorrência, elaborei um projeto sobre relatos de mulheres, imigrantes ilegais, analfabetas, latino-americanas nos Estados Unidos. Surpreendentemente ganhei a bolsa e fui por um ano a Nova York. Além de coleções de textos teóricos lidos e discutidos, dei cabo da proposta em poucos meses.

Imediatamente, porém, constatava a ausência de exames de um dos problemas nacionais brasileiros mais expostos à época: a evasão de brasileiros, ou dizendo de outra forma, a fuga de um contingente de brasileiros que não tinha ainda suas experiências registradas. Isso foi o 
bastante para sair a campo e enfrentar o enorme desafio de registrar e proceder análise dos enredos narrados. Contei, para tanto, com a ajuda de alunos que, já interessados em História Oral, se prontificaram a ajudar na recolha de mais de 700 narrativas. Este trabalho resultou no livro Brasil Fora de Si: Experiências de Brasileiros em Nova York. ${ }^{12}$

Um dos temas mais salientes no longo e exaustivo processo de documentação dos casos foi a presença e liderança feminina nesse processo. Foi assim que reconheci a importância da dança, e nela a proximidade da prostituição de brasileiras como GoGo dancers. E daí notei também o paralelo com homens que, afinal, se aproximavam da prostituição. Dessa forma, depois de publicado o livro, me vi convidado a pensar o mesmo procedimento de brasileiras e brasileiros no espaço internacional. A Europa, onde nossos patrícios assumem papel de relevo na prostituição foi, assim, um cenário natural, de continuidade. E tudo foi inesperado, por mais imaginasse algum conhecimento. A atividade na Europa era muito mais ligada a questões culturais, afeitas ao uso do corpo e aos estereótipos da imagem dos brasileiros e, principalmente, das brasileiras ligadas ao sexo. Tive que aprender a ouvir, solicitar a reflexão pessoal dos colaboradores e tratar de transmitir da melhor forma possível os casos que, afinal, mostravam mais do que se pode supor pelos filtros convencionais.

Um dos temas mais pertinentes da produção de História Oral remete ao modo de produção dos projetos e seu consumo. Além das clássicas questões que norteiam pesquisas de História Oral (quando e por quê), faz-se imperioso dizer "como", "de quem" e "para quem". A vocação da História Oral, naturalmente, remete a um de seus polos mais sensíveis: ao público em geral. Reforça-se que não se trata de procedimento que valoriza exclusivamente o consumo. Ao se pensar em História Oral como mecanismo de desnaturalização de fatos e versões da vida, remete-se também à participação na feitura do projeto, em todas as etapas. Tem-se claro que uma das maiores qualidades da História Oral é sua determinação social. É essa virtude aliás que marca a vocação de "História Pública" inerente à História Oral. Partindo-se do suposto que elege os colaboradores como elementos ativos, donos de suas narrativas existenciais, fica exposto o sentido social das participações.

$\mathrm{Na}$ história qualquer pessoa é coletiva, pois não se entende a existência humana destituída de participação, desde a língua que se fala, aos detalhes todos da vida, é o grupal que explica a individualidade. Perceber no colaborador o filtro da complexidade da vida coletiva exige também que se elaborem recursos para a acolhida dos resultados. A questão "História

12 MEIHY, José Carlos Sebe Bom. Brasil Fora de Si: Experiências de Brasileiros em Nova York. São Paulo: Parábola, 2004. 
Oral para quem", assim, ganha inerência à vida de todos. E não se pensa apenas em respostas estampadas em livros, em teses ou artigos escritos. Não. A ampliação do público consumidor das experiências que nos envolve, a todos, é parte do projeto. Neste sentido, as redes sociais, a internet, o cinema e a televisão se inscrevem nos planos de divulgação.

No meu caso pessoal, aconteceu ser convidado, depois da elaboração do livro Brasil fora de si: experiências de brasileiros em Nova York, e também ser consultado, sobre a vida de dançarinas brasileiras nos Estados Unidos. A pesquisa, feita entre 1999 e 2000, foi acolhida como possibilidade de indicação para enredo da novela "América" que, contudo, devido à gravidade do atentado de 2001, teve o cenário mudado para Miami. Depois dessa experiência, outras aconteceram, com destaque para o livro Prostituição à Brasileira, ${ }^{13}$ sobre o tráfico e uso de mulheres no jogo da prostituição internacional.

Há setores sensíveis à presença da história oral como parte integrante das próprias pautas socioinstitucionais. Ainda que não seja privilégio exclusivo das universidades, alguns setores acadêmicos reclamam participações destacadas em suas áreas. O jornalismo, a psicologia social, toda área de saúde, por exemplo, isoladas ou em conjunto, partilham facetas comuns ao uso de entrevistas. Sobremaneira, as disciplinas voltadas à formação de professores merece relevo. Há uma instintiva insistência no olhar para dentro dos caminhos escolares, e faz parte do autoconhecimento escolar voltar-se para si. A história e as experiências de professores é um desafio que exige reflexão, pois afinal, não dá para tratar a escola como um organismo frio, sem vida. A humanização do processo educacional, com urgência, demanda registros e trocas de experiências. No âmago da investida contida nos livros sobre Direitos Humanos, Gênero e Diversidade na Escola, ${ }^{14}$ bate um coração que se mostra pulsante na medida em que coloca em tela não apenas o aluno/outro, mas de forma vibrante o "quem somos e como chegamos até aqui".

A partir da História Oral, veio a temática da História Pública para o Brasil, muitos anos atrás. Esta questão me é muito cara. Com o caminhar dos processos de profissionalização do historiador - e também dos demais segmentos voltados à educação - colocou-se como prioritário o apego (conveniente, mas muitas vezes excessivos) às teorias e conceitos geridos e exercitados em outros espaços culturais, notadamente fora do país. Consequência eloquente disso é o diálogo entre pares. Não é

13 MEIHY, José Carlos Sebe Bom. Prostituição à Brasileira: Cinco Histórias. São Paulo: Contexto, 2015. 14 MEIHY, José Carlos Sebe Bom et al. Série Direitos Humanos, Gênero e Diversidade na Escola. 12 vols. São Paulo: UFABC/MEC/Pontocom, 2016. Disponível em: <http://cursos.ufabc.edu.br/digitalplural/direitoshumanos-genero-e-diversidade-na-escola/materiais-didaticos/livros/>. Acesso em: 13 dez. 2018. 
preciso esforço para notar que a escrita da história e das demais reflexões disciplinares, tem sido feita para circulação limitada, entre seus emissores. O grande público, a massa da população fica, quase sempre, alijada de participação. Por ironia, exatamente a escola que se alça como mãe da inclusão, exclui a parcela maior da sociedade que não entende o linguajar expresso pelos intelectuais. É na correção dessa rota que se pensa na História Pública.

Por lógico, isto não exclui a existência de uma história profissional, fundamentada em pressupostos epistemológicos, mas o que se quer é a flexibilização de modos de recepção ampla. Dizendo de outra maneira, não se duvida da possibilidade de acatamento de uma produção intelectual que se expresse em linguagem acessível. Em termos filosóficos, o que se preza é que além dos emissores, se pense de maneira mais sensível e articulada nos receptores, no público. Há outros ângulos a serem considerados nesse esquema, pois o público deve ser respeitado em seus níveis de entendimentos.

$\mathrm{O}$ avesso disto implica tirar do intelectual seu poder de explicador único, dono de um paternalismo que identifica o público como "outro", incapaz de se justificar como protagonista. A moderna História Oral tem a ver com isto na medida em que, segundo algumas interpretações, trabalha com o conceito de "colaboração" (co-labor-ação, ou ato de trabalho conjunto) e, sob tal crivo, questiona o arrogante conceito de autoria. Transformando esta resposta em pergunta é de se questionar: de quem é a minha história? Quem tem direito de contá-la? Só os profissionais da universidade podem dar vida à minha/nossa experiência?

Já questionaram-me acerca de entrevistas em que as histórias de vida eram atravessadas ou explicadas por sonhos. Esta pergunta carrega um desafio enorme: a relativização da objetividade narrativa. O outro lado da suposta verdade histórica interessa tanto ou mais do que seu lado tangível, identificável, expresso por meio de documentos e técnicas usuais. Em primeiro lugar, convém a lembrança firmada por Marc Bloch que delega a cada geração o dever da reescrita da história. Assim, temas como a família, a mulher, a criança, não existiam há poucos anos, novas abordagens dão caminho à "outras histórias" e "vistas de outros patamares".

Entre tantos aspectos, a subjetividade tem sido uma alternativa possível. Isso convida a formulação de outros tópicos de investigação e interpretação. O medo, o amor, o ódio, passam a ganhar espaços analíticos e exigem, para tanto, sondagens que permitam dimensões. Os sonhos noturnos se apresentam como uma dessas possibilidades. O importante, porém, não é apenas se considerar os supostos já definidos 
por autores como Freud ou Jung; muito mais importante é ver como passar do plano narrativo teórico para o escrito, contando com a interpretação do próprio narrador. Com a ajuda de alguns colegas tem sido feitas algumas investidas. Eu particularmente levei a cabo um projeto junto a mulheres analfabetas que se dispuseram a contar e analisar os próprios sonhos. Uma outra experiência foi feita em escolas, com narrativas contadas e/ou colhidas pelos próprios alunos em sala de aula. Esta experiência está publicada sob o título de Aventuras oníricas: experiências pedagógicas em narrativas, textos e imagens. ${ }^{15}$

A passagem do oral para o escrito é um dos desafios mais complexos das culturas em geral. Sob a ditadura do grafado, de regra, se descredencia o oral como se fosse vago, mutável, sem precisão. Tais marcas expressivas, contudo, merecem consideração, pois elas também são, em si, históricas. Ao longo da construção do mundo erigido sob a ordem econômica, o alinhamento da escrita alfabética e dos algarismos se imperam como critério de domínio e poder. Cabia aos alfabetizados o governo e ordenamento das sociedades. E também sua exclusão do mundo dito civilizado. Ao longo dos séculos os chamados subalternos têm emergido como problema e eles clamam por participação no quadro geral das sociedades. Juntamente com estes grupos economicamente mal colocados, outros segmentos também padecem de submissão às regras erigidas sempre de cima para baixo, de quem detém mandos. Nesta linha, as mulheres, negros, índios, homossexuais, pobres em geral são marginalizados.

Não cabe dizer que não se advoga "dar voz aos vencidos", mas sim transformar os meios de produção de saber em mecanismos de pertencimento. Um dos exercícios mais preciosos neste processo remete a transformação do oral no escrito. Porque se valoriza o fim social acima dos alcances disciplinares, leva-se em conta a finalidade da boa redação como filtro para a ampliação do consumo dos produtos intelectuais. A transcriação não é um conceito, mas um processo de transformação de um a outro estado de linguagem. Haroldo de Campos evocou algumas experiências em literatura - em particular, derivadas de Ezra Pound e James Joyce para proceder a um processo de tradução. Empresta-se, pois das adaptações derivadas dessa prática a mudança do oral para o escrito. Não vejo problemas entre o uso da boa expressão literária na história - em particular na História Pública. Cabe lembrar que vivemos um mundo em que a chamada interdisciplinaridade está em pauta.

15 MEIHY, José Carlos Sebe Bom; LEMOS, Ana Paula; TRIANI, Felipe. Aventuras Oníricas: Experiências Pedagógicas em Narrativas, Textos e Imagens. Salvador, BA: Pontocom/Unigranrio, 2015. Disponível em: <http://www.editorapontocom.com.br/l/36/Aventuras-on\%C3\%ADricas>. Acesso em: 13 dez. 2018. 
Perguntam-me se já fiz um balanço de quantas histórias de vida ouvi... e quais ainda gostaria de ouvir. Seria necessário um longo tempo para responder a esta questão. Aliás, ela me fez lembrar uma passagem atribuída a Pascal quando, no século XVII, teria dito que escrevia uma longa carta porque não tinha tempo para escrever uma mais curta. Segundo essa lição, minha resposta seria extensa, pois não estoco tempo no momento.

Não sei dizer quantas histórias de vida já fiz. Esta contabilidade é praticamente impossível, posto ter acompanhado muitos pesquisadores em projetos compartidos. Seguramente tenho algumas centenas de gravações, algumas ainda em rolos e fitas K7. Sou daqueles que pensam que a fidelidade deve se restringir a aspectos íntimos das pessoas, assim, em vista das histórias que gravo não tem uma ou sequer dúzias de preferidas. Todas me marcam e, volta e meia, retomo algumas delas e as elejo como preferentes, até que outras tomem lugar.

Se a pergunta remetesse a projetos, diria que o afeito ao exame das prostitutas brasileiras no exterior me diz mais. Por se tratar de questões ligadas ao uso do corpo, à percepção cultural da brasilidade no estrangeiro, às submissões impostas por características do comportamento sexual, tudo em conjunto, marcou demais minha experiência. Não me recordo de ter deixado fora de consideração alguma história gravada. Por certo, algumas tiveram que ser contornadas a fim de proteger os colaboradores. Cito, à guisa de exemplo, uma prostituta que contava com detalhes nome, endereço, situações concretas - suas peripécias com drogas, propinas de políticos. Nesses casos, recomenda-se o artifício das histórias orais anônimas, onde então se transformam os dados identificáveis e, mediante aviso dos leitores, processase alterações. É claro que tem casos em que o colaborador não quer que suas histórias sejam publicadas, mas esta é outra situação.

Gostaria de ouvir todas as histórias que puder. Todas. Lembro-me de um autor que disse: "Deus fez os seres humanos porque gosta de histórias". Somos um pouco deuses porque amamos as histórias de todos.

Sobre refletir, todas as histórias, sem exceção, me fizeram refletir. Não me lembro de nenhuma desprezível. Também não aceito os limites sobre a capacidade de dizer. De uma ou de outra forma, temos sim que nos expressar. O processo transcriativo existe exatamente para favorecer a narrativa. Houve situações em que me senti próximo da impossibilidade, mas tais circunstâncias foram vencidas com o auxílio dos próprios colaboradores. Costumo voltar a eles 
e trocar ideias sobre aspectos difíceis. Tal procedimento convida a outra reflexão, a pensar na necessidade de entrevistas múltiplas em vez de entrevistas únicas.

Durante décadas dediquei-me à relação oralidade/escrita. Foram ingentes esforços, em particular trabalhando em um Departamento de História (USP) prezador da documentação feita por outrem, arquivada e rara. É óbvio que tive que acompanhar a evolução dos conceitos documentais e ampliação do conceito de fontes. A iconografia, o cinema, o desenho, entraram com eficácia na elaboração de projetos, mas eu pessoalmente tenho enorme dificuldade em trabalhar com a comunhão de imagens e narrativas. Tenho incentivado a nova geração de oralistas à prática de gravações com imagens, os chamados vídeos. Eu pessoalmente não tenho conseguido e atribuo isso à longa jornada de definição da transcriação. Acompanho colegas que se sentem bem trocando a transcriação pela edição. É possível. É louvável, mas eu ainda não atingi este estágio. Creio que os mais jovens se sentem mais à vontade para tais aventuras. E tomara que continuem, pois é um caminho inevitável.

Infelizmente, perdi algumas histórias que deixei para gravar depois, e o depois não aconteceu. E não foram poucas. Uma das mais importantes foi com o professor Simão Mathias, pois ele queria ter a história gravada, concordou algumas vezes, mas por situações banais eu deixei de fazê-lo. O pior é que isto se repetiu com outros casos, inclusive com Gabriela Leite, no momento em que ela pediu para ter sua história registrada e eu, morador de outra cidade, fiquei aguardando chance de gravar: ela morreu antes. Quanto a conseguir, sou insistente e negocio de várias formas, só não pago para entrevistar. Com as lições que aprendi, sem dúvida alguma, não deixaria mais passar a oportunidade: quer ser entrevistado, concordo com isso, é prá já. Algumas vezes fui convidado a contar minha história pessoal, bem como o sentido da história oral em minha vida. Tenho resistido e sei que isto é injusto. Tenho no momento compromisso com uma pessoa que, ao longo de anos, tem insistido nisso. Vou fazer, comprometo-me, e, tomara que não aconteça comigo de morrer antes...

Volto a dizer que todo e qualquer projeto de história oral deve responder: de quem, como, quando, por quê e para quem? Há algo mais que pode ser acrescentado e que ajudaria dar mais sentido a esta resposta: ninguém passa imune a uma entrevista bem-feita de História Oral. Há, portanto, um lado terapêutico inerente ao processo narrativo. A história oral de vida é transformadora, quando levada a sério. Isto contudo não deve ser confundido com autoajuda. Quando as histórias de vida são trabalhadas e colocadas a público, ganham sentido coletivo e isto torna-se a razão de ser dos projetos de História Oral.

Diria aos jovens que fazer projetos e criar sentido de pertencimento é dimensionar de forma atual o papel mediador do intelectual no mundo moderno. Acho que a democracia 
implica conhecimento dos cidadãos e, nesta linha, todas as histórias merecem lugar. É claro que umas histórias são mais necessárias e urgentes que outras, mas isto depende da compreensão e alcance dos projetos e determinações pessoais. Eu, pessoalmente, acho que um bom tema e uma boa colônia a ser entrevistada seriam os moradores de rua. Este tema me chama a atenção por remeter a um conjunto de problemas atuais: organização familiar, trabalho, moradia, aceitação social, efeitos psicológicos...

Não há mentira em História Oral. Tudo que é dito deve ser considerado em si. Aliás, é exatamente a mentira, o desvio, a deformação, a tal visão de mundo, que interessam na História Oral. O que é sugerido é a boa organização de redes para a coleta de histórias. A discussão sobre verdade ou mentira, sobre realidade ou variações interpretativas deve decorrer das análises das entrevistas. O registro é uma coisa, bem diferente é a reflexão de argumentos diferentes. Suponhamos um projeto sobre a tortura no período ditatorial, uma rede de torturados daria uma versão sobre a luta pela justiça; a rede de torturadores promoveria outra versão. Cabe ao analista comentar e proceder a análise. Não nos esqueçamos: as fakenews são uma realidade.

O respeito é tudo em História Oral. Talvez, em termos acadêmicos, poucas áreas de estudo exijam tanto, em termos de ética, como a História Oral. Jamais gravar uma história sem autorização do colaborador. Jamais publicar algo que não seja legitimado anteriormente. A não exposição das pessoas, por mais interessante que seja o caso, não pode confundir a história revelada com um furo de reportagem. Há situações inesperadas de choros, de silêncios, de conveniência de interrupção das entrevistas. Tudo deve ser acatado em comum acordo.

A vida é uma ladainha de surpresa. Eu, depois de viajar muito, passados anos de trabalhos com imigrantes, tendo estado nas proximidades do Líbano, nunca me vi convidado a visitar a terra de meus pais. Aposentado, carente de descanso, optei por uma viagem que imaginava turística. Foi uma revelação completa. A modernização daquele país é incrível mas, na mesma ordem, a manutenção de traços do passado surpreende. Um dos fatores mais importantes para mim foi notar a resistência de traços mnemônicos da cultura local. Seja pela música, comida, formas de relacionamento cotidiano, nota-se a presença do passado. A tradição de tolerância se expressa no convívio de religiões diferentes e isso ultrapassa o impacto das guerras. Atualmente existem no Líbano vários acampamentos que acolhem os sírios evadidos de seu país pela guerra, as fronteiras identitárias se mostram como fértil tema para se pensar os denominadores comuns de grupos (língua árabe, por exemplo) e suas diferenças. Compreender estas situações em outros espaços culturais ajuda a nos entender também.

Venho de um clã de comerciantes clássicos. Com uma família que sempre valorizou a sobrevivência pelo trabalho comercial, tive as dificuldades inerentes aos processos de 
adaptação interiorana. Meus pais tinham projetos para mim, filho homem mais velho. Mas, ao mesmo tempo, eles queriam que todos estudassem e eu acabei por achar meu caminho em paralelo às atividades parentais. Como recurso possível, optei por ser professor de história e nessa seara achei o caminho da História Oral. Caminho sem volta. 